体育学研究，34：235-243，1989.

\title{
通動選手のバーンアウト症候群に関する概念規定への試み
}

\author{
岸順 治 ${ }^{1)}$ 中 込四 郎 ${ }^{21}$
}

\section{An approach to clear the definition of athletes' burnout syndrome}

\author{
Junji Kishi ${ }^{1}$ and Shiro Nakagomi²
}

\begin{abstract}
Considerable research has been conducted on burnout syndrome in the field of human services. Lately this concept has been applied to the psychological problems of the athlete, and has often been discussed as athletes' burnout. However, some current definitions are vague, or overly inclusive. Staleness and overtraining similar to burnout have been discussed without proper differentiation of these concepts. For application of this concept to the athlete, a certain standard must be defined. Therefore, it is attempted in this paper to consider and clarify burnout syndrome by reviewing previous studies of burnout. The review was looking on three essential factors-a premorbid character, situation and symptoms. The cases which met our criteria for burnout syndrome were compared with other clinical figures.

Common characters as melancholic type or immodithymia were recognized as a premorbid character. Further it was assumed that burnout cases would cling tenaciously to objects or situation (e.g. job), and then suffer serious stress which eventually leads to the disease.

Next, based upon this review we attempted to present some conceptual framework for the study of athletes' burnout. Staleness can be regarded as one prodrome or symptom of burnout in sports. Overtraining can be regarded as a situational factor in which psychosomatic dissipation or burnout occur rather than as a category of disease. In determining the diagnostic criteria of athletes' burnout, we have to consider not only a consequence such as a decrease in athletic motivation and a drop out from sports but also a premorbid character and situations, especially the clinging to sports in object relationship.
\end{abstract}

(Japan J. Phys. Educ., 34: 235-243, December, 1989.)

\section{はじめに}

近年, バーンアウト症候群 (burnout syndrome）に関する研究が米国を中心に活発化し ている。この症候群は，医療施設のスタッフに 認められた，長い間の目標への献身が十分報い られなかったときに生じる情緒的・身体的消耗

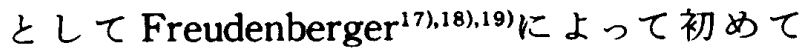
報告されたものである゙1).
以来, 教師 ${ }^{9), 10), 38), 59)}$, 看護婦 ${ }^{28), 37), 56), ~ ソ ー シ ャ ~}$ ル・ワーカー50),54), アスレチック・トレー ナー51,6),20)，コーチ(1),7) といった対人サービスを 行なら職種を対象とした研究が行なわれてい る.そして，この現象を運動選手に適用し，さ かんに議論が行なわれるようになってき

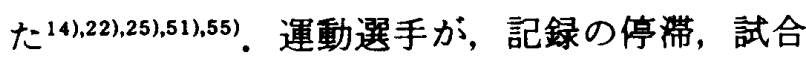
での敗北，怪我などによって，無気力，抑うつ といった心理的問題を呈するという報告は従来
1) 岐阜メモリアルセンター 干502 岐阜市長良福光大野2675-28

2) 筑波大学体育科学系 干305 つくば市天王台 $1-1$ - 1
1. Gifu Memorial Center, Gifu City, Gifu, (502)

2. Institute of Health and Sports Sciences, University of Tsukuba, Tsukuba City, Ibaraki, (305) 
から行なわれている421,43). また，近年の競技ス ポーツの高度化に伴うトレーニングの低年龄 化, 長時間の練習, 勝利志向の重視等は, 運動 選手に対し強いストレスの原因となっており， その弊害が指摘されつつある。保坂・杉原 ${ }^{271}$ は, 運動選手の記録の停滞によって学習性無力感 (learned helplessness) が形成されることを示 している.こうした運動選手の心理的問題に, バーンアウトといら新たな枠組みを導入するこ とによって，これまで個々独立して研究が進め られてきた問題の同一水準での解明が可能とな る。運動選手のバーンフウトは，単に成績の低 下やスポーツからの離脱といった問題に終わる ものではなく, 対人関係や学生競技者の修学上 の問題, 精神衛生といった日常生活の様々な領 域に波及する，現場での選手指導だけでなく， 選手への心理臨床的働きかけを行なら上でも， バーンアゥトの理解は有力な手がかりを与えて くれるようである。

しかしながら，現在のところバーンアウトを どら捉えるかといら点で研究者間に若干の混乱 が認められる8),12),18)。これは，症候群といら形態 による包括性とともに, Shank ${ }^{52)}$ が指摘するよ らに，この用語が米国社会で一時流行語となり 扗大解釈されてきた経緯によるよらである。統 一した定義がないことによって，この用語を恣 意的に使用している研究も認められる。 また, 予防論・治療論が先行し, 現象そのものの究明・ 理解は十分に行なわれていない。メカニズムを 十分に究明することによって，上り効果的な対 処が可能となるはずである。そして，本来対人 サービスの職種に限定されていた現象を，その まま運動選手に適用するにあたっては慎重に取 り报わなければならない.今後, 運動選手のバー ンアウトについて研究を進めるにあたって, 一 定の概念的枠組みを提出しておくことが必要で あると考えられる。こうして出される概念的枠 組みは，作業仮説として実証的研究を促するの であり，そして，ょり精度の高い説明が可能と なっていくはずである。

したがって, 本稿の目的は以下の 2 点である。
1 つは, バーンアウトに関する従来の研究を概 観し，この現象を明確に捉えること。ここでは， 曖昧性をできるだけ排除するために，この現象 を心理臨床的見地から一臨床単位として捉える といら立場をとっている，いま1つは，運動選 手のバーンアウトについて，オーバートレーニ

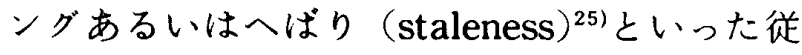
来から論じられている現象との関連，さらには 診断・鑑別上の問題について検討し，その概念 的枠組みを設定することである。

\section{パーンアウト症候群についての文献的考察}

異なる領域での対象疾患者から得られた知見 を運動選手のバーンアウトに適用する場合，必 ずしも同列に扱らことはできない，しかし，運 動選手のバーンアウトの発症機序あるいは症状 の特異性を考虑しながらも，精神医学や臨木心 理学領域からの情報は, 運動選手のバーンアウ トの明確化をはかるらえで有奻な手掛かりを与 えている。ここでは，これまでに種々の角度か ら行なわれてきたバーンフウト研究を, 病前性 格一発病状況一症状といら枠組みからを好 $ろ^{301}$.こうしたフプローチによって, 病像の有機 的・構造的把握が容易になると考えられる。そ して,この枠組みの中で得られた知見に基づき， 他の精神疾患との関係について論じ，この病像 の臨床的位置づけを行なら。

\section{1. 病前性格}

不適応あるいは心理的問題を呈する要因に は，パーソナリティ次元の問題が関連している ことが多い，病前性格（基本性格）という観点 からの詳細な研究は行なわれていないようであ るが，バーンアウトになりやすい人の性格特徴 は，多くの報告で共通項を見い出すことができ る.すなわち, 情熱的, 仕事熱心, 理想主義, 完全主義, 几帳面, 他者志向, 強迫傾向といっ た特徵11),19),36),47),52)である. Farber ${ }^{12)}$, Gieck et $\mathrm{al}^{20)}$ は, このような特徵を冠状動脈性心葴疾患 を引き起こしやすい性格特徵として知られるタ イプ A 行動特徵 (type A behavior pattern) として類型化している。 また，宗像・椎谷 ${ }^{38}$ は中 
学校教師のバーンアウト状態とタイプ A 行動 特徵との間に正の相関を報告している，確かに 両者には重複する部分もあるが，バーンアウト の病前性格において認められている他者志向 (people oriented) や主張的行動の欠如 (lack of assertive behavior $)^{39,521}$ といった特徵は，タイ プ A 特性者のもつ攻撃性, 他者支配性といった 特徵とは対照的なものである。バーンフウトに おける，批判に対する敏感さ，他者に認められ

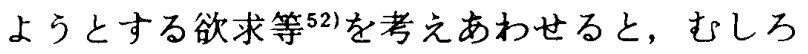
単相性らつ病の病前性格として知られるメラン コリ一親和型性格特徵・執着性格といら類 型31)、2)にほぼ合致すると思われる。

\section{2. 発病状況}

（1）高すぎる理想の設定

バーンアウトの発病状況の一つに, 非現実的 期待あるいは高い理想を自分自身に課すことが 指摘されている19),24),35),56). 当然これは, 理想主 義, 完全主義といった前項で指摘した性格特徵 が基盤となっている. Fischer ${ }^{16)}$ はバーンアウト 患者を「「苦痛を受けても自己の理想を放棄した り低めたりせず，最後まで対象にしがみつき， 結果として生じるすべての緊張や消耗を受けな がらさらに激しく働く人々である」と述べてい る. 仕事への過度の同一視によって, 理想と現 実とのギャップが一種の悲哀体験となり，そこ での適応的対処行動ができないことがバーンア ウト発症の契機となっているようである。

（2）慢性的ストレス

バーンアウトを仕事上の慢性的ストレスによ る反応として捉充，多くの実証的研究が行なわ れている。ここでは主に, Maslach and Jackson ${ }^{34)}$ の開発した Maslach Burnout Inventory（MBI）を使って，バーンフウトと関連を 持つ職場の環境的・組織的ストレスの影響を明 らかにしょらとする試みが中心である。仕事上 の役割の暧昧さ (role ambiguity) と役割の混乱

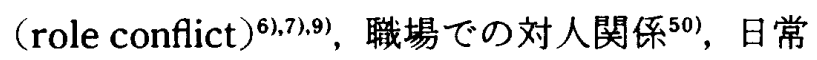
の苛立事, 仕事の土気の低下 ${ }^{38)}$, 仕事の量6),10)な どといった変数とバーンアウトの程度との相関 が報告されている。しかし，同じ労働条件でも
バーンフウトに陥る人とそうでない人がい $ろ^{16), 39)}$. ストレスは受ける側の性格特徵の違い によって, 状況の認知的解釈及び被る影響の違 いをもたらすことになる。バーンフウトの病前 性格の輪郭がある程度はっきりしていることを 考えると，バーンアウトは，ある種の性格特性 者が持つ素因に基ついて出現するストレス的状 況の結果として捉えるべきであろう。つまり， ストレスはバーンフゥトになりやすい性格特徵 を持つ人に症状を引き起こす誘因の一つとして 捉えることができる。

\section{3. 症状}

バーンアウトの症状は実に多様である．精神 症状と身体症状に大別され，個人によってその 様態は異なる。精神症状としては, 不安, 抑ら つ, 罪悪感, 感情の鈍麻, 気分の変動, 怒り・ 焦燥などといった欲求不満反応, 他者に対する 敵意ないし慣疑的態度, 全能感を伴う妄想, 自 殺念虑など5),13),177,35),37)が報告されている，身体 症状としては, 疲労感, 頭痛, 消化器系・心缄 血管系不調, 睡眠障害, 体重の減少あるいは増 加, 浅い呼吸, 心拍数の増加, 性的不能, 薬物・ アルコール依存など5),177,37)が報告されている。

Maslach and Jackson ${ }^{34)}$ は, バーンアウト患 者の臨床観察, 面接, 自由記述の質問紙による 調査によって，バーンフウトの 4 つの特徽を想 定し因子分析の結果, 次の 3 因子を抽出してい る。情緒的消耗 (emotional exhaustion), 個人 的成就感 (personal accomplishment), 離人症 (depersonalization) である。また, Perlman and Hartman ${ }^{45)}$ は, バーンアウト研究を概観 し，その特徵を情緒的・身体的消耗，生産性の 低下, 過度の離人体験の 3 つにまとめている。 これは, Maslach and Jacksonの 3 因子とほぼ 対応するものであり，バーンアウトの症状はこ の3つに包括できるようである。

\section{4. うつ病との関係}

バーンアウトを従来からの臨床単位と直接, 比較・対応するという試みはほとんど行なわれ ていないようであるが，報告されている症状に は, 抑らつ, 自尊心の低下, 絶望感, 感情の鈍 
麻, 気分の変動といったらつ病に類似した症状 あるいは抑らつ反応を多く認めることができ る。ここでいうらつ病とは，精神病範檲のもの でなく，比較的軽症の神経症範䁣（抑らつ神経 症）のものであるが，近年はこうした軽症のう つ病が増加しており，その病態も非常に多様化 の傾向にある ${ }^{30)}$. また, バーンアウトの病前性格 はらつ病のそれとほぼ一致するものと考えてょ いであろら。したがって，バーンアウトをらつ 病の一覀型とする見方も出てくる。笠原・木村30) のうつ病の分類に従えば，バーンアウトはI 型 のメランコリー親和型のらつ病に近いようであ る. 厇瀬 ${ }^{26)}$ は, 競争社会において, 闘いの前から 無気力になるアパシー型うつ病, 闘いに参加し ながら形勢不利とみるや䦥いを諦め抑らつに逃 避する逃避型らつ病に対し，メランコリー親和 型のうつ病を最後まで闘いながら抑うつに陷る 型と述べている。バーンアウトにおける対象と のかかわり方を考えると，メランコリ一親和型 らつ病と発病状況においても類似した特徵を持 つといえる。

Fischer ${ }^{16)}$ は, バーンフウト患者の精神分析的 観察から, 彼らの仕事への過度の同一視は, 自 分についての誇大感 (grandiose self) を抱いて おり，対象（仕事）がこの自己愛を満たすため の供給源（narcissistic supply）となっているた めであると指摘している。つまり，自分の能力 と一致しない過大な理想自己を持ち，そこでの 対象関係 (object relation)に颃いて対象を自己 愛的に同一視 (narcissistic introjective

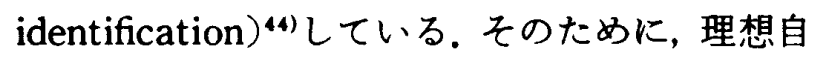

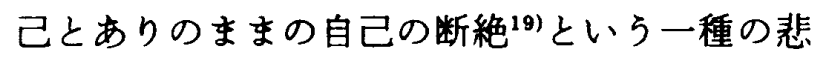
哀体験によって，これまで仕事を精力的に行な らといら形で対象に向けられていた攻撃が，自 己に向きかえられて症状を呈するといら発症機 序である。

この発症機序は，らつ病のそれとほぼ同じも のといってよい.しかしながら，らつ病にみら れる生活全般にわたる浸透性の抑らつと異な り，バーンアウトのうつは症状の主導を形成し ているわけではなく，少なくとも初期において
はある対象（仕事）に限定されているといら指 摘がある(16),19).さらに,バーンアウトの 1 つの特 徵である他者への攻撃・敵意的態度はうつ病で はほとんど認めることはできない.5つ病では， 多くの場合, 自黄, 自魝といら形で自己への攻 揧となり，表へ出たり，他者へ直接表出される ことは稀である゙1)。このバーンアウトの攻撃性 について, Fischer ${ }^{16)}$ は自己愛的外傷 (narcissistic trauma）による反応とみており，自尊心低 下による欲求不満反応の 1 つとして捉えること もできるが推測の域を出ない。したがって，病 前性格や発病状況レベルではらつ病にかなり近 く，心理的発生メカニズムもほぼ同じとみてよ いと思われ, 少なくともらつ病, 特にメランコ リー親和型のうつ病に近縁する病態ということ はできるよ5である。

\section{量勒選手のパーンアゥト}

今のところ, 運動選手のバーンフウトに関す る実証的研究は行なわれていないようである. Rowland ${ }^{511}$ は, 運動選手のバーンアウトの症例 と診断のための指針を報告している。しかし， 彼の報告するバーンアウトはストレスによる成 績の低下といら包括的視点からの，オーバート レーニングや，近親者の死去による心理的外傷 によるものであり，前項で捉えたバーンフウト とは必ずしも一致しない。また, Henschen ${ }^{25)}$, Feigley ${ }^{14}$ は, 運動選手のバーンフウトの予防 論・治療論を展開しているが，現象の十分な理 解を待たずにその対応策を講じることには慎重 であらねばならないと考えられる。

従来から報告されている運動選手の不適応例 の中には，前項でまとめられたバーンフウトに 類似した症例を認めることができる。例えば, Ogilvie and Tutko(3)の報告するデプレッショ ン・プローン・フスリーツ (depression prone athletes), ペイサー2), 小川42)および高田ら57)の 報告する症例である。 また，著者らの運動選手 を対象とした臨床経験でもバーンフウトに近い 症例を認めて招り 济，こうした選手への効果的 な対応策を講じるためにも，概念の共通性を求 
め，より基礎的な研究を行ならことが必要であ る。まずは, 研究の出発点として, 運動選手の バーンアウトを考えるらえでの一定の枠組みを 検討する作業が必要であると思われる。ここで は，前項でまとめられたバーンアウトの病前性 格一状況一症状といら観点を基に，運動選手の バーンアウトの明確化を試みる。

1. へばり (staleness)・オーバートレーニン グとの関係

スポーツ場面では, 以前からへばり,オーバー トレーニングといった現象がさかんに議論され てきた、へばりすオーバートレーニングあ統一 的定義はなく，研究者の立場によって捉えかた は異なっているようである。当然，バーンアウ トとの混乱が予想される。ここでは，前項で捉 えたバーンアウトをへばり及びオーバートレー ニングと比較し，その関連について検討する。

Jensen and Fisher ${ }^{29)}$ は，へばりをオーバート レーニング, 練習の単調さ, 持続した情緒的ス トレスによる一般的な疲労としており，症状と して反射の遅延，関心喪失，長期間にわたる体 重の减少，倦点感，活力の低下，焦燥感をあげ ている。また, Hanson ${ }^{23)}$ は, へばりをオーバー トレーニングと同義に扱い, 疲労, 抑らつ, 倦 怠感とその他，喉・筋肉の痛みなどの不特定症 状をあげ，その主要な特徵は気分状態（mood state）の低下であるとしている。へばりとは 種々の要因による活力の減退あるいは気分の低 下といらことができる。したがって，

Henschen ${ }^{25)}$ む指摘するように, へばりはバーン アウトの前駆状態として，あるいは一症状とし て位置づけることができると思われる。

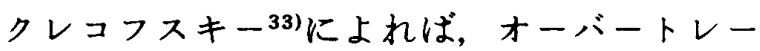
ニングは，一定の方法で一定の期間トレーニン グを続けてきた人およびトレーニングを続けて いる人において，そのトレーニングのあり方が 身体組織の機能を阻害し，その状態が続いたも のであると主張している. Kereszy ${ }^{321}$ は, スポー ッにおいて成績の低下をもたらす要因を器質的 疾患, オーバートレーニング, 過度の緊張, 一 過性の不快の 4 つに分類し，オーバートレーニ
ングを身体的・心理的影響による慢性的疲労に よって引き起こされる神経系の失調であると述 べている。オーバートレーニングの症状として は，種々の生理的症状の他に精神的症状として 抑うつ, 焦燥, 活力の低下, 不眠, 頭痛, 自尊 心の低下など3),32),33)，バーンアウトの症状とほ ぼ重複している。両者とも症状の発現様態は個 人によって異なり，また，オーバートレーニン グに至る背景には, 練習熱心, 完全主義, 理想 主義といったパーソナリティ次元の要因が関係 している場合が考えられる。このように，オー バートレーニングに関わる報告の中にも，バー ンアウトと共通する側面を認めることができ る。しかしながらオーバートレーニングを疾 病単位として捉えることは誤解を招き，心身の 消耗を引き起こす状況因として位置つけたほう が適切であると考えられる。なぜなら，運動選 手のバーンフゥト発症に括ける状況要因（発病 状況)の 1 つして，オーバートレーニングが, 今後種々の角度から検討されることになると思 われるからである，従って概念的には，両者を 別次元で捉えることが望むしいといえる。これ までにオーバートレーニングとして報告されて きたものと、バーンフウトを区別する基準とし ては，バーンアウト特有の病前性格, 状況, ま た，それに伴う本人のトレーニングの認知の仕 方を考慮することが妥当であろう。

\section{2. 診断・鑑別の問題}

運動選手のバーンアウトを診断・鑑別する方 法として, 報告されている症状からの症候論的 視点がある．特に運動場面で問題となるのは， 競技意欲の低下であろう。この場合，綀習によ る疲労, 試合後の虚脱状態など一過性のものは 除き，慢性的症状を対象としなければならない。

しかしながら，症候群といら形態に由来する 症状の多様性・個別性という問題がある。ささ に，報告されている症状は，対人サービスの職 種に認められたものであるから，運動選手に 同じ症状が認められるとは限らない，特に， Maslach and Jackson ${ }^{34)}$ 離人症因子に代表さ れる他者への敵意・慣疑的態度は, 対象 (仕事) $=$ 
他者というこの種の職業の特殊性が反映されて いる可能性がある。したがって，症状からの鑑 別だけでは不十分であるといえる。

一方，測定尺度は研究者によっては独自の チェックリストを作成しているが，実証的研究 に最も頻繁に使用され，一応の信頼性・妥当性 が保証されているのは, Maslach and Jackson'34)の MBI である。この尺度は，バーン アウトの特徵である情緒的消耗, 個人的成就感, 離人症の 3 因子を質問紙化したものである。こ れは，対人サービスの職種を対象として作成さ れているため, 今後この尺度を背景として運動 選手に適用する際には修正して用いることにな るだろ5。しかし，この種の尺度は，とここで をバーンアウトにするかといらカットオフポイ ソトの問題があり，また，症状からの把握であ るために，バーンアゥト状態あるいはバーンア ウト傾向の程度の把握ということになる，運動 選手のバーンアウト研究に拈いても，バーンア ウト尺度を適用すると同時に，個々の症状に 至った過程を検討する必要がある。そして，こ の発症の過程を明らかにすることにより，指導 上有益な示唆を得ることになる。

Smith ${ }^{55}$ は，バーンアウトによるスポーツか らの離脱 (drop out)とそうでない離脱をシボー とヶリーの社会的交換モデルを用いて区別す ることを提唱している。これは，スポーッ活動 による報酬（reward）と負担（cost）との関係 である結果 (outcome) と, 活動への個人の要求 水準にあたる比較水準 (comparison level), 現 在の活動と他の活動との魅力の比較である選択 水準 (comparison level for alternatives) の 3 者関係において離脱か残留かが決定されるとい ら公式である。Smithは，従来のスポーツから の離脱に関する研究を概観し、ほとんどの場合， 選択水準が結果と比較水準を上回ったことによ る離脱であるとした上で，バーンフウトではこ らした関係は成立せず，比較水準は高いけれど も，結果が選択水準を下回って離脱するとい5 説明を試みている。つまり，バーンアウトでは 現在の活動に強い兔力と要求水準を持っていな
がら，結果を上回る多大な負担によって離脱に 至るのである。このモデルは, 活動へのかかわ りと固執の程度からの把握であり，バーンדウ トに打ける対象への執着あるいは自己の理想の 引き下げができないといら発病状況における見 解と一致したものである。ささに，病前性格を 加えた病因論的視点を採用することによって， 一層有効な診断・鑑別が可能となるだろう。

\section{まとめと今後の課題}

運動選手のバーンアウトという新たなカテゴ リーを提唱するために，これまでに報告されて きているバーンアウト研究を, 心理臨床的視点 から, 病前性格一発病状況一症状といら枠組及 で捉えた。メランコリー親和型・執着性格とい ら性格特徵が，この病態の素因として大きな役 割を担っていることが示唆された。この性格ゆ えに対象に固執し多大なストレスを被り，様々 な症状を呈するのである。このような構造を， バーンアウトの中核として捉えることができ る。特に対象への固執といらことがバーンアウ トを論じる上での，1つの鍵となっている。

そして，これまでオーバートレーニングの表 題で報告されてきたものには，運動選手のバー ンフウトと読みかえることが可能な内容が散見 している.しかし、オーバートレーニングはバー ンアゥトの状況因の一つとして位置づけること の方が適当と考えられる。また，へばりはバー ンアウトの前駆状態あるいは一症状として捉え ることが可能であることを示唆した。また，運 動選手のバーンフウトを診断・鑑別するには, 単に競技意欲の低下，スポーツからの離脱と いった結果だけでなく，競技への固執の様態を 考慮する必要があることが示唆された。した がって,バーンアウト発症に至るまでの過程が, 今後の研究の課題となってくるようであ

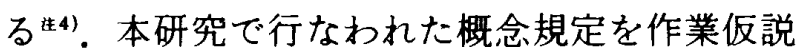
として，実証的研究を進める必要がある。

Feigley ${ }^{14)}$ が指摘するように，おとなしく真面 目で練習熱心で，目標の高い選手は，コーチか ら理想的な選手として受けとめられている。こ 
らした選手の中にはメランコリー親和型・執着 性格に近い者があり，現場では特に問題視され ることはなかった。このような性格は，おそら くそれまでの生育史にその起源を求めることが できる，特に，運動選手の場合，それまでの競 技活動での経験様式がバーンフウト発症の機序 に関連していることが予想される。また，自己 と競技との対象関係，さらには競技場面でのス トレス要因などが問題となってくる。ここで得 られたバーンアウトに関する病前性格，発病状 況，症状といった基本的構造を踏襲し，これま で対人サービスの職種について論じられてきた 概念を運動選手に扗大・援用することは，運動 選手の不適応や成績の低下といった問題に新た な視点を提供することになるだろう。

\section{注}

注 1) ハーンフウト症候群は, 精神医患の診断名と して正式には採用されていない，著者らが本文中 で試みている運動選手のバーンアウトの概念規 定を, 従来の疾患分類に求めるならば,「メランコ リー親和型 らつ病」あるいはキールホルッ(Kielholz)の説明する「消耗抑らつ」(Erschöpfungsdepression)に近いと考えられる。後者については， 本論文の査読者の1人からも指摘されたことで ある。しかし、「バーンアウト」といら名称をあえ て用いた理由は以下のよらなことからである。

・本研究の主たる目的は, 運動選手のバーンフウト を従来の垁患分類の中に整理しなおすことでは ない、今後さらに・゙ーンフウト研究を積み重ねて いくことにより, 臨床像への共通理解を得ること ができ, 精神病理学上での診断について, 改めて 検討課題となっていくものと考えている.

・スポーツ心理学領域でのバーンフウト研究は着 手されたばかりである。伝統的な疾患カテゴリー の枠内で研究するよりる，現時点では一応独立さ せて，それらとの関連を論じながら研究を進めて いくことの方が望ましいと考えている.

・運動選手を対象としたハーンアウト研究がすで にいくつか認められており，また今後むバーンフ ウトの表題のもとに報告されることが予想され る.それらの研究と関連づけえでも，ハーン アウトをキーワードとして採用することが妥当 であると考えた。

注 2 ) 5つ病の発病に際して病因的役割りを担っ
ている性格特徵として，下田 ${ }^{53)}$ が執着性気質，テ レンバッハ ${ }^{58)}$ がメランコリー親和型性格をそれ ぞれ報告している。執着性気質は，仕事熱心，凝 り性, 徹底性, 正直, 几帳面, 強い義務責任感と いら特徵である。このような人々は，一度生じた 感情がさめることなくその強さが持続し，むしろ したいに強まって活動を持続し，その結果疲労の 頂点でらつ病に至る。また,メランコリ一親和型 性格の特徽は, 几帳面之自己要求の高さ, 仕事・ 対人関係での秩序の重視, 仕事の量と精度, 他者 への良心性などである.両者には類似点が多くう つ病の病前性格として一括して論じられている。 いずれす状況の変化に対して柔軟な対応に欠け ることが問題となっている。この性格類型は我が 国と一部のドイッ語圈で認められているのみで 米国では一般的なむのではない，そのために， バーンアウトの研究にこの性格特徵からの記述 がないるのと考えられる。しかし，米国でのバー ンアウト研究においては，バーンフウトに陥りや すい性格特徴の個々の記述に終わっており，それ らの妥当と思われる共通側面を記述しよ5とし たとき，さらに洗練され，まとまったものとして この性格類型を取り上げた。我が国でバーンフウ トを研究するにあたって, 必然的に浮かび上がっ てくる性格類型であると考えられる。

注 3 ) 本研究は著者らの論述の稚拙や，こうした テーマにおける研究遂行上の倫理の問題が問わ れ，公刊されるまでにかなり時間を要した。その 間, 運動選手のバーンアウトに関する事例報告を 行なら機会が以下のよ5に与えられた。本文の注 ならびに参考文献として新たに付け加えさせて いたたくことをお許し願いたい.

- "On the athlete's reconfirmation of ego identity and the past crisis mode," Seoul Olympic Scientific Congress, Abstracts, Pp. 372, 198840)

・「運動選手のハー・ウト（Burnout）についてー1 症例の竸技歴を通してー」スポーツ心理学研究, 15- $1: 102-03,1988^{41)}$.

注 4 ）運動選手のバーンフウト発症に至る過程を 検討一発症機序の解明一する場合, 必然的に臨床 事例を扱らことになる. 惧重に行ならと同時に, 著者ら自身の心理臨床技法のさらなる習熟をは かっていくことが大切となる。

付記：本稿の作成にあたり，贵重な御示唆を賜りまし た筑波大学教授市村操一氏，ならびに岐阜大学助教授鉿 木 壮氏に深く感謝いたします。 


\section{引用・参考文献}

1）青井和夫,「小集団の構造と機能」青井和夫・綿貫 撞治・大橋幸（編），集団・組織・リーダーシッ ブ、今日の社会心理学第 3 巻, 培風館, 1962, pp. $80-83$.

2 ベイサー(藤原健固訳)，スポーツ心理学ース ポーッによる心理社会的障害一, ベースボールマ ガシン社, 1976.

3) Bell, B., "The overtraining syndrome," American Rowing, 18-2:40-42, 1986.

4) Caccese, T.M. and Mayerberg, C.K., "Gender differences in percieved burnout of college coaches," Journal of Sport Psychology, 6 : 279 $-88,1984$.

5) Campbell, D., Miller, M.H. and Robinson, W. W., "The prevalence of burnout among athletic trainers," Athletic Training, 20-1:110 $-13,1985$.

6) Capel, S.A., "Psychological and organizational factors related to burnout," Research Quarter. ly for Exercise and Sport, 57-4:321-28, 1986.

7) Capel, S.A., Sisley, B.L. and Desertrain, G.S., "The relationship of role conflict and role ambiguity to burnout in high school basketball coaches," Journal of Sport Psychology, 9 : 106 $-17,1987$.

8) Chance, P., "That drained-out, used-up feeling," Psychology Today, 15: 88-95, 1981.

9) Crane, S.T. and Iwanicki, E.F., "Perceived role conflict, role ambiguity, and burnout among special education teachers," Remedial and Special Education, 7-2:24-31, 1986.

10) DePaepe, J., French, R. and Lavay, B., "Burnout symptoms experienced among special physical educators: A descriptive longitudial study," Adapted Physical Activity Quarterly, 2 $-3: 189-96,1985$.

11) Edelwich, J. and Brodsky, A., Burnout : Stages of disillusionment in the helping professions, Human Services Press: New York, 1980.

12) Farber, B.A., "A critical perspective on burnout," in Farber, B.A. (Ed.), Stress and burnout in human service professions, Pergamon : New York, 1983. pp. 1-20.

13) Farber, B.A. and Miller, J., "Teacher burnout: A psychoeducational perspective," Teacher College Record, 83-2 : 235-43, 1981.

14) Feigley, D.A., "Psychological burnout in highlevel athletes." Physician and Sportsmedicine, 12-10:109-19, 1984.

15) Firth, H., Mcintee, J., Mckeown, P. and Britton, P.G., "Maslach burnout inventory: Factor structure and norms for British nursing staff," Psychological Reports, 57 : 147-50, 1985.

16) Fischer, H.J., "A psychoanalytic view of burnout," in Farber, B.A. (Ed), Stress and burnout in human service professions, Pergamon : New York, 1983. pp. 40-45.

17) Freudenberger, H.J., "Staff burn-out," Journal of Social Issues, 30-1 : 159-65, 1974.

18) Freudenberger, H.J., "Burnout : Contemporary issues, trend, and concerns," in Farber, B.A. (Ed.), Stress and burnout in human service professions, Pergamon: New York, 1983. pp. 23-28.

19) Freudenberger, H.J. and Richelson G., Burn out: The high cost of high achievement, Anchor Press : New York, 1980.

20) Gieck, J., Brown, R.S. and Shank, R.H., "The burnout syndrome among athletic trainers," Athletic Training, 17-1:36-42, 1982.

21) Gold, Y. and Michael, W.B., "Academic selfconcept correlates of potential burnout in a sample of first semester elementary-school practice teachers: A concurrent validity study," Educational and Psychological Measurement, $45:$ 909-14, 1985.

22) Gould, D., "Understanding attrition in chil. dren's sport," in Gould, D. and Weiss, M.R. (Eds.), Advances in pediatric sport sciences, Vol. 2. Human Kinetics : Champaign, 1987. pp. 61-85.

23) Hanson, P., "Illness among athletes : An overview," in Strauss, R.H. (Ed.), Sports medicine, W.B. Saunders Company : Philadelphia, 1984. pp. $79-90$.

24) Harison, W.D., "A social competence model of burnout," in Farber, B.A. (Ed.), Stress and burnout in human service professions, Pergamon: New York, 1983. pp. 29-39.

25) Henschen, K.P., "Athletic staleness and burnout : Diagnotic, prevention, and treatment," in Williams, J.W. (Ed.), Applied sport psychology, Mayfield Publishing Company: California, 1986. pp. 327-42.

26）去瀬徹也，抑万つ症候群，金原出版，1986. pp. 65 .

27）保坂か抢る・杉原隆「競泳選手の記録の変化上 Learned Helplessnessとの関俰」スポーツ心理 学研究, 12-1:16-21, 1985.

28）稲岡文昭・松野か、忹る・宮里和子「看護婦にみら れる Burn Out とその要因に関する研究」看護, 36-4 : 81-104, 1984.

29) Jensen, C.R. and Fisher, A.G., Scientific basis of athletic conditioning, 2nd Ed., Lea and Febiger: Philadelphia, 1979. pp. 298-99.

30）笠原 嘉，木村 敏「弓つ状態の臨床的分類に関 する研究」精神神释学雑誌, 77-10:715-35, 1975. 
31 管原 嘉「うつ病の病前性格について」管原 嘉 編)，躁うつ病の精神病理 1，弘文堂，1976. pp. $1-29$.

32) Kereszty, A., “Overtraining," in Larson, L. (Ed.), Encyclopedia of sport sciences and medicine, Macmillan : New York. 1971. pp. 218-22.

33 クレコフスキー(高橋華王訳), スポーッマンの 健康とは何か, ベースボールマカジン社, 1979 . pp. 154-58.

34) Maslach, C. and Jackson, S.E., "The measurement of experienced burnout," Journal of Occupational Behaviour, 2 : 99-113, 1981.

35) McConnell, E.A., "How close are you to burnout," in McConnell, E.A. (Ed.), Burnout: In the nursing profession, C.V. Mosby Company : St. Louis, 1982. pp. 98-103.

36) McConnell, E.A., "Potential causes of burnout," in McConnell, E.A. (Ed.), Burnout: In the nursing profession, C.V. Mosby Company : St. Louis, 1982. pp. 111-18.

37 McMinn, S., "Burnout," Nephrology Nurse, 1 $3: 8-10,1979$.

38 宗像恒次・椎谷淳-..「中学校教師の然点つ状態 の心理社会的背景」精神徫生研究, 33：129-53, 1986.

39) Nagy, S., "Burnout and selected variables as components of occupational stress," Psychological Reports, 56:195-200, 1985.

40) Nakagomi, S., "On the athlete's reconfirmation of ego identity and the past crisis mode," Seoul Olympic Scientific Congress, Abstracts, pp. $372,1988$.

41) 中远四郎「運動選手のバーナウト (Burnout)に ついてー1. 提例の競技歴を通して一」スポーツ 心理学研究, 15-1: 102-03, 1988.

42)小川捷之「アポ口的すきたスポーツマンーある サッカ一選手の挫折一」新体育，49：296-305, 1979.

43) Ogilvie, B.C. and Tutko, T.A., Problem athletes and how to handle them, Pelham Books: London. 1966. pp. 173-92.

44)小此本敬吾,「精神分析からみたらつ病」宮本忠雄 (編), 躁うつ病の精神病理 2 , 弘文堂, 1977. pp. 249-79.

45) Perlman, B. and Hartman, E.A., "Burnout: Summary and future research," Human Rela. tions, 35-4:283-305, 1982.

46) Pines, A. and Kafry, D., "Occupational tedium in the social services," Social Work, 23-6: 499 $-507,1978$.
47) Pines, A., Aronson, E. and Kafry, K.D., Burnout : From tedium to personal growth. Free Press: New York, 1981.

48) Powers, S. and Gose, K.F., "Reliability and construct validity of the Maslach Burnout Inventory in a sample of university students," Educational and Psychologial Measurement, 46: 251-55, 1986 .

49) Rafferty, J.P., Lemkau, J.P., Purdy, R.R. and Rudisill, J.R., "Validity of the Maslach Bur. nout Inventory for family practice physicians," Journal of Clinical Psychology, 42-3: 488-92, 1986.

50) Rosenthal, D., Teague, M., Retish, P., West, J. and Vessell, R., "The relationship between work environment atrtributes and burnout," Journal of Leisure Research, 15-2:125-35. 1983.

51) Rowland, T., "Exercise fatigue in adolescents: Diagnosis of athlete burnout," Physician and Sportsmedicine, 14-9:69-77, 1986.

52) Shank, P.A.. "Anatomy of burnout," Park and Recreation, 18-3:52-58, 1983.

53)下田光造「躁5つ病の病前性格について」精神神 経学雑誌, 45-2:101-03, 1941.

$54)$ Shinn, M., R $\phi$ sario, M., Morch, H. and Chestnut, D.E., "Coping with job stress and burnout in the human services," Journal of Personality and Social Psychology, 46-4:864-76, 1941.

55) Smith, R.E., "Toward a cognitive-affective model of athletic burnout," Journal of Sport Psychology, 8: 36-50, 1986.

56) Storlie, F.J., "Burnout: The elaboration of concept," in McConnell, E.A. (Ed.), Burnout : In the nursing profession, C.V. Mosby Company : St. Louis, 1982. pp. 81-85.

57）高田千恵子・田村宏・石淵真理子 - 藤永 隆・ 下山定利・柚木 伿・黒梅恭芳・高田利武「部活 動体験による青年期不適応に就いて一事例研究 一」日本教育心理学会第29回総会発表論文集, pp. $528-29,1987$.

58) テレンパッ(木村 敏訳), メランコリー, み すず書房, 1978.

59) Zabel, R.H. and Zabel, M.K., "Factors in burnout among treachers of exceptional children," Exceptional Children, 49: 261-63, 1982.

（昭和63年 1 月 8 日受付） 